\section{The underbelly of the Berea: Challenges to orthodox planning for the creation of sustainable suburban neighbourhoods in South Africa}

\author{
Robynne Hansmann, Gilberte Lincoln \& Godfrey Musvoto
}

http://dx.doi.org/10.18820/2415-0495/trp72i1.2

Peer reviewed and revised January 2018

${ }^{*}$ The authors declared no conflict of interest for this title or article.

\begin{abstract}
Sustainable neighbourhood development is a global urban planning policy concern for the $21^{\text {st }}$ century. In the global South, these concerns persist alongside increasing population and poverty levels in cities. In South Africa's established former apartheid neighbourhoods, the challenges of creating sustainable neighbourhoods from the current post-colonial neighbourhood are unclear and contradictory. Former largely mono-functional suburban neighbourhoods of the apartheid period are undergoing changes in form, function and demography. Using the case of Berea suburban neighbourhood in the metropolitan city of eThekwini (Durban), the article explores the responsiveness of orthodox land-use planning to sustainable neighbourhood change from 1994. It focuses on a historical review of orthodox planning vis-à-vis recent policy and land-use change dynamics in the Berea. Data used include a content analysis of the Berea General Plans from 1857, Town Planning Schemes and related documents, purposively selected interviews, observations, GIS mapping of planning applications, and analysis based on South African demographic census data from 2001 to 2011 . The article concludes that former largely monofunctional orthodox suburban neighbourhood planning is insufficiently responsive to heterogeneity trends on the Berea.
\end{abstract}

Keywords: Informality, neighbourhood change, orthodox planning, planning policy, physical form and function, sustainable neighbourhood planning

\section{DIE ONDERBUIK VAN DIE BEREA: UITDAGINGS AAN ORTODOKSE BEPLANNING VIR DIE SKEPPING VAN VOLHOUBARE SUB-STEDELIKE WOONBUURTE IN SUID-AFRIKA}

Die ontwikkeling van volhoubare omgewings is 'n bekommernis vir globale stedelike beplanningsbeleid vir die $21^{\text {ste }}$ eeu. Hierdie bekommernisse tesame met groeiende bevolking en vlakke van armoede in stede duur voort in die globale Suide. In Suid-Afrika se gevestigde voormalige apartheidswoonbuurte, is die uitdagings vir die skep van volhoubare buurte vanuit die huidige post-koloniale omgewingsveranderingsdinamika onduidelik en teenstrydig. Voormalige hoofsaaklik mono-funksionele voorstedelike woonbuurte van die apartheidstydperk ondergaan tans veranderinge in vorm, funksie en demografie. Met behulp van die Berea-gevallestudie in die substedelike omgewing in die stad van Durban ondersoek die artikel die reaksie van ortodokse grondgebruikbeplanning vir volhoubare omgewingsverandering vanaf 1994. Dit fokus op 'n historiese oorsig van die ortodokse beplanning vis-à-vis die huidige dinamikabeleid en grondgebruikverandering in Berea. Data wat gebruik is, sluit in 'n tydreeksanalise van die Berea grondgebruikskema van 1857 tot die hede, doelgerigte geselekteerde onderhoude, waarnemings, GIS-kartering van beplanningsaansoeke, en analise gebaseer op Suid-Afrikaanse demografiese sensus data vanaf 2001 tot 2011. Die artikel dui aan dat voormalige hoofsaaklik mono-funksionele ortodokse sub-stedelike omgewingsbeplanning onvoldoende reageer op heterogeniteittendense op Berea.

Sleutelwoorde: Beplanningsbeleid, fisiese vorm en funksie, informaliteit, omgewingsverandering, ortodokse beplanning, volhoubare omgewingsbeplanning
KAROLO E SENG NTLE/E SENG HANTLE YA BEREA: DIPHEPETSO TLHOPHISONG / TOKISETSONG YA TOKA "ORTHODOX PLANNING" BAKENG SA HO THEA/BOPA DITIKOLOHO TSE NANG LE BOTSITSO DITOROPONG KA HARE HO AFRIKA BORWA

Ntshetsopele e tsitsitseng ya tikoloho ke ngongoreho ya molao wa lefatshe wa hlophiso/tokisetso ya setoropong bakeng sa mongwahakgolo wa " $21^{\text {st }}$ century". Karolong e ka Borwa ya lefatshe, dingongoreho tsena di tswella pele mmoho le ho eketseha ha setjhaba le maemo a bofutsana ditoropong. Ditikolohong tsa kgale tsa kgethollo Afrika Borwa; diphepetso tsa ho etsa ditikoloho tse nang le botsitso ho tswa ho ditikoloho tsa hajwale tsa ka mora bokolone, ha di a hlaka, hape di a hanyetsana. Ditikoloho/dibaka tsa metsetoropo tsa nakong ya kgethollo, tseo e neng e le tsa bodulo feela (mono-functional), di fetoha sebopeho, le tshebediso ya tsona le bongata ba batho "demography". Re sebedisa mohlala wa tikoloho ya Berea toropo e kgolo ya eThekwini (Durban), atikele ena e hlahloba karabelo ya thero/ tokisetso ya tshebediso ya lefatshe ka mokgwa wa toka "orthodox" bakeng sa phetoho e tsitsitseng ya tikoloho ho tloha ka 1994. E tsepamisa mohopolo hodima tlhatlhobo ya nalane/histori ya thero/tokisetso ya toka "orthodox", ho fapanyetsana le molao wa hajwale le dikarolo tsa phetoho ya tshebediso ya lefatshe, Berea. Pokello ya dintlha (data) e sebedisitsweng e kenyelletsa thatlhobo ya dikahare tsa Berea General Plans ho tloha ka1857, Town Planning Schemes le ditokomane tse amehang, dipuisano tse kgethilweng ka boomo, ditlhokomediso, mmapa wa GIS bakeng sa dikopo tsa hlophiso le thathobo e itshetlehileng hodima pokello ya dintlha tsa palo ya setjhaba (census data) ho tloha ka 2001 - 2011. Atikele ena e qeta ka hore thero/tokisetso ya tikoloho ya motsetoropo wa kgale o neng o na le tshebediso e le nngwe ya bodulo feela (mono-functional) o ikarabella ka matla mekgweng e sa tshwaneng, Berea.

Ms Robynne Hansmann, Department of Town and Regional Planning, Durban University of Technology, PO Box 1334, Durban, 4000, South Africa. Phone: 0313732666, e-mail: <robynne@dut.ac.za>

Gilberte Lincoln, Department of Town and Regional Planning, Durban University of Technology, PO Box 1334, Durban, 4000, South Africa. Phone: 0313732220, e-mail: <lincolng@dut.ac.za>

Dr Godfrey Musvoto, Department of Town and Regional Planning, Durban University of Technology, PO Box 1334, Durban, 4000, South Africa. Phone: 0313732665, e-mail: <godfreym@dut.ac.za> 


\section{INTRODUCTION}

This article critiques the legacy of orthodox modern neighbourhood planning in the context of postapartheid South Africa suburban neighbourhood change and planning. Using the Berea suburb in the metropolitan city of eThekwini (Durban), the case study explores the responsiveness of neighbourhood scaled orthodox planning to post-apartheid sustainable cityplanning policies and dynamics. The Berea, some 2000 hectares, located adjacent to the west of the Inner City, is a former apartheid neighbourhood in the city of Durban which falls under the planning and administrative jurisdiction of present-day eThekwini Metropolitan Municipality. Typical of South African suburban neighbourhoods developed during the colonial and apartheid era, urban planning of the Berea was based on modern 'orthodox' suburban planning principles that were infused with racial segregation and class stratification, resulting in enduring urban and neighbourhood spatial inequalities.

From 1994, planning in the city of Durban and the Berea, in particular, occurs in the context of Integrated Development Planning (IDP). As a process, IDP is a local policy manifestation of Agenda 21, the United Nations global policy framework action plan for promoting sustainable development in different localities across the globe. The IDP, as the plan outcome, seeks to promote the creation of sustainable human settlements through mixed land usage, racial and income mix of the population and good local governance, among other measures. This is reflected in the local government legislative framework by the Local Government Municipal Systems Act (No. 32 of 2000), which compels every municipality in South Africa to prepare IDPs to guide development within their administrative jurisdictions (RSA, 2000). The study analyses the spatial transformation and sustainability agenda that has impacted on the material and social conditions of citizens on the Berea, and, in particular, on how land-use management shapes the dynamics of urban transformation. The normative principles, articulated in policy and legislation have been critically assessed, including the eThekwini Integrated Development Plan, the Spatial Development Framework Report 2013/2014 (eThekwini Metropolitan Municipality, 2012), the Spatial Land Use Management Act (No. 16 of 2013) (RSA, 2013), in which the principles of integrated sustainable development and compact city are articulated.

This article provides a literature review focusing on the background of the study, highlighting the domains of orthodox planning and sustainable neighbourhoods. An outline of the South African and eThekwini Municipality sustainable neighbourhood planning policy context follows. The interplay of the eThekwini Municipality, as regulator of development and land use, through schemes, market forces, and what lies in between, creates the backdrop. Finally, the methodology, findings, discussion of findings and recommendations are presented. This paper identifies the conflicts of residual orthodox planning instruments in practice following the paradigm shift and changing assumptions from orthodox planning to normative, sustainable planning.

\section{SUSTAINABILITY AND PLANNING: DEFINITIONS AND DOMAINS}

The philosophies associated with sustainable development originate from the 1970s: The Ecologist's Blueprint for Survival (Allen, Allaby, Davoll \& Lawrence, 1972: 1-43); the Brundtland Commission in 1987, which defined the now widely accepted definition of sustainable development as "development which meets the needs of the present without compromising the ability of future generations of meeting their own needs" (Brundtland, Khalid, Agnelli et al. 1987: 27), and the Earth Summit in 1992, in which sustainable development was established as the most important policy for the $21^{\text {st }}$ century, and out of which the Rio Declaration and Agenda 21 emerged as "the new philosophy, in which principles of futurity, equity, global environmentalism and biodiversity must guide decision-making" (Andrew, 1995: 109). Sustainability is a normative concept to guide future action, and is often referred to as the "triple bottom line", which considers environmental quality, economic prosperity and social justice and, more recently, expanded definitions argue for the inclusion of the governance domain (Yigitcanlar \& Kamruzzaman, 2015: 14679). The latest addition is the United Nations 2030 Agenda for Sustainable Development, which declares that extreme poverty, environmental degradation and climate change can only be tackled through implementing the Sustainable Development Goals (SDG) (Stewart, 2015: 289).

Pieterse (in Bruyns \& Graafland, 2012: 52-53) argues for definitions that focus on sustainable lives and livelihoods that are open to local context and the "potential of sustainable urban development", rather than the prescripts of "world class cities". Pieterse and others (Parnell \& Pieterse, 2010: 158; Schensul \& Heller, 2011a: 26-27; Brenner, Marcuse \& Mayer 2012: 39; Harrison \& Todes, 2015: 158) caution of advancing integrated sustainable development in the context of a highly exploitative capitalist economic system that produces, reinforces and maintains uneven spatial outcomes and multiple lines of inequality in the built environment, more especially in cities in the South. These include various institutions that perpetuate differential impact on the built environment, such as the land market, degree of civic engagement, contextually unresponsive instruments of landuse management, regulations and building standards, restricted informal use of public spaces, and differentiated public investment in infrastructure, public transport and public utilities.

The term 'the global South' reflects an urban reality, where complex differentiation and inequalities co-exist, and suggests a departure point where "global inequalities and the persistent production and 
reproduction of those inequalities lie at the root" of developmental challenges (Miraftab \& Kudva, 2015: 3). The term helps frame orthodox planning processes in the context of Durban, to recognise that these inequalities emanate from 'historical underpinnings' of colonialism, apartheid and capitalism, and that they impact on the shape and form of local urban planning.

Orthodox planning in this study is assumed to be a largely state-centred activity that privileges the public interest and mediates private-sector interest in favour of the general amenity and general well-being of the public (Gunder \& Hillier, 2009: 77; Hall, 2015: 436-437). Embodied in the Garden City movement of the early $20^{\text {th }}$ century, orthodox planning can be described as an ensemble of ideas on planning and property development principles to achieve an environment based on "amenity and environmental quality" (Stubbs, Ratcliffe \& Keeping, 2009: 7). It sought to address the challenges posed by concentrated Victorian era cities through promoting decentralized connected cities, and not dissimilar to the concerns of present-day sustainable development.

In both the global North and South, orthodox planning has been informed by substantive, procedural and normative planning domains. Substantively, during the late $19^{\text {th }}$ and early $20^{\text {th }}$ century, the focus was on industrial growth and addressing the public health concerns posed by crowded industrial cities. This was through neighbourhood planning, using schemes that regulated land-use zones, building height and densities, and sanitation provision. Procedurally, during this period, orthodox planning was a highly technical and state-led activity based on positivist methodological inclinations. In the South African context, the dynamics of orthodox planning at that time was similar to the developed world. The main difference is that orthodox planning was partly introduced and modified on the basis of racialized spatial segregation. In the late $19^{\text {th }}$ and early $20^{\text {th }}$ century, substantive orthodox planning tools such as zoning and schemes, with planning threshold standards, were introduced to address material, public health and racial segregation agendas. According to Mabin and Smit (1997: 197), during the First World War, planning in South Africa had to respond to rising costs, housing shortages and the growth of slums in cities. It was also in a context where outbreaks of tuberculosis and influenza, in 1914 and 1919, respectively, were blamed on Blacks living in slums (Maylam, 1995). Parnell (1993: 472-473) and Maylam (1995: 27) identify the role of planning as part of public health concerns in the early racial frameworks of segregation. Maylam (1995: 27) highlights that, from 1910, the discourse on public health that was reflected in the Public Health Act of 1919, viewed disease in racial terms and promoted racial segregation as a solution to the urban health problems emanating from the crowded living conditions of Africans. With the implementation of apartheid in 1948, racialized spatial segregation and orthodox planning became central to this political agenda. From the late $19^{\text {th }}$ century until the apartheid period, orthodox planning was largely a technocratic and state-led process. It relied on positivist rational models of procedural planning such as rational comprehensive planning and site survey analysis.

In both the global North and South, orthodox modern planning is widely criticized for its preconceived utopian assumptions of how cities should function, which have little to do with how cities work in reality (see Jacobs, 1961; Lefebvre, 1996; Harvey, 2016). Since the second half of the $20^{\text {th }}$ century, in both post-modern and post-colonial city contexts, orthodox modern planning has also been critiqued for its relative unresponsiveness to heterogeneity of city populations and economies. In post-apartheid South Africa, for instance, orthodox neighbourhood planning has been under scrutiny for its lack of receptiveness to the policy of creating sustainable human settlements through densification, mixed land use, racial and income mix of the population, among other measures (Dewar \& Uytenbogaardt 1991; Harrison, 2002: 6). Notably, Jacobs (1961: 143) critiqued 'orthodox' modern planning, in general, and neighbourhood planning, in particular, in relation to the idealism of how cities should function, but which articulates into contradictory physical planning outcomes. She argues for diversity and heterogeneity in neighbourhood planning, by anchoring development around multiple primary economic functions and by attracting vibrant shared use of facilities for various socio-economic groups. She critiques mono-functional, separated land uses.

Whilst some of the major structuring elements of orthodox modern planning remain relevant at present, they have evolved in response to new challenges and conditions in the built environment, most notably in the conceptualisation of neighbourhood planning and design under the 'New Urbanism' paradigm. Principles of the neighbourhood concept have appeared in many traditional neighbourhood development (TND) projects across the cities of the world (Patricios, 2002: 21; Harrison, Todes \& Watson, 2007: 119), and include walkability, connectivity, mixed use and diversity, densification, mixed housing, green transportation and sustainability (LeGates \& Stout, 2015: 372). Likewise, there has also been a global shift in the planning process, which emphasizes communicative and collaborative planning processes with the view of eradicating poverty, reducing carbon emissions, creating employment and promoting spatial equity. In South Africa, similar shifts are identified. The collapse of apartheid initiated spatial planning interventions in cities that were introduced alongside existing orthodox planning tools. These frameworks include local government restructuring, integrated neighbourhood designs, low-income housing provision, local economic development and basic municipal services provision. At the same time, the planning process shifted from being largely a state-led technocratic 
process to an inclusive interactive process, as outlined in the principles from the Local Government Municipal Systems Act (No. 32 of 2000).

\section{SOUTH AFRICAN POLICY AND LEGISLATIVE CONTEXT OF THE STUDY: SHIFTING AMBIGUITIES}

The establishment of the Union of South Africa in 1910 is widely regarded as the period in which orthodox modernist planning was introduced, infused with racial segregation intentions of the colonial government (Mabin \& Smit, 1997: 196). Between 1914 and 1918, the Garden City movement was introduced to South Africa in Cape Town by Richard Stuttaford, a merchant and member of the South African Cabinet (DuncanBrown, 2000: 155). While the case study area of the Berea, unlike Durban North, does not show direct Garden City principles, the influences on elements of layout are evident in land-use arrangements.

The apartheid era from 1948 onwards saw the intensification of orthodox modern planning in cities, using the "exclusionary logic of apartheid spatial form" defined by racial spatial segregation and the implementation of the Group Areas Act (No. 41 of 1950), which compelled legal racial spatial segregation in cities and towns (Harrison et al., 2007: 24). Zoning provided the main planning mechanism to implement segregation. Different races (Whites, Blacks, Coloureds and Indians) were allocated different residential zones in cities and towns that were peripherally located from the city, serving mainly the needs of industry, and separated by physical environmental features such as green belts, highways, or industrial zones, that acted as buffer zones. The White racial group was mostly located in suburban residential locations relatively close to the city centre, and enjoyed the amenity of orthodox neighbourhood planning principles. For other racial groups, land use was primarily based on mono-functional dormitory suburbs, with limited socio-economic opportunities and differential land-use planning systems (McCarthy \& Smit, 1984: 57-58;

Schensul \& Heller, 2011b: 6).

Planning in exclusively White residential areas was informed by the Garden City movement and orthodox planning. Provisions were made for land-use zoning for housing densities and height, land-use controls, where the provision of facilities such as parks, schools and hospitals and the physical planning design were in line with the neighbourhood planning concept. With the collapse of the apartheid administration in South Africa in 1994, orthodox modern planning came under intensified scrutiny (Harrison et al., 2007: 39-40). The focus changed from the creation of relatively mono-functional settlements to promoting compact city ideas and principles of new urbanism as pioneered in South Africa by Dewar and Uytenbogaardt (1991). This, in turn, placed attention on the receptiveness and adaptability of the orthodox planning system to complex challenges of spatial transformation of cities and towns to the new settlement discourses at a neighbourhood level.

The current architecture for stateled planning in South Africa is, for the first time in two decades, bound in a single piece of national legislation dealing with normative frameworks through to schemes, namely the Spatial Planning and Land Use Management Act (No. 16 of 2013) (SPLUMA). The legislation links normative-based principles within the Spatial Development Frameworks (SDFs) to land-use management zoning scheme. The normative principles apply to spatial planning, land-use management and land development in order to address spatial justice, spatial sustainability, efficiency, spatial resilience and good administration (RSA, 2013). Nel (2016: 79) argues that, in the context of SPLUMA, the mechanism of zoning as a land-use management tool, has been critiqued for being exclusionary and socially, economically and environmentally unsustainable. Issues such as differential systems of land-use management are raised, where former townships, traditional areas and informal systems allow for incremental introduction of schemes. This article concurs with previous research to suggest that zoning can exclude who can or who cannot have access to development rights, as well as some of the limitations of land-use control systems breaking down between wealthier and poorer areas in the context of case studies in Cape Town (Watson, 1993: 155).

Land use on the Berea is managed through the mechanism of the Town Planning Scheme (TPS). Despite changes in the national planning system to prepare new land-use scheme and planning by-laws $(R, 2013)$, land use in the case of the eThekwini Municipality is still managed through the 1973 Durban Town Planning Scheme (City of Durban, 1973), established under the former apartheid-led administration and provincial planning legislation, the Natal Town and Planning Ordinance (No.27 of 1949), as amended (TPO), (Province of Natal, 1949). The Berea Scheme of 1965 was adopted by the Durban City Council on 19 June 1967 and came into operation on 19 May 1969. However, with the creation of the Comprehensive Set of Regulations, these related to the Berea and other Scheme Districts within the erstwhile Durban Municipal Area, as a single set of regulations adopted on 14 December 1973. Hence, the land-use management of the Berea has, since December 1973, been through the Durban Town Planning Scheme, using the same Comprehensive Set of Regulations, as amended from time to time. More recently, land-use change decisions are reviewed against the Berea Urban Core Extension Plan (2012) as a more localised expression of city-wide spatial development plans (lyer Design Studio, 2012a: 11). This plan is built upon the work from the Interim Land Use Guidelines Project (2002), which included North and South Berea areas, and produced an earlier version of the Berea Urban Core Extension Project, to rationalise zones and introduce land-use intentions.

Furthermore, within the context of legislative changes, the Special 
Consent procedure related to the Scheme persists as the main mechanism for initiating land-use change. While the TPO was replaced by the KwaZulu-Natal Planning and Development Act (No. 6 of 2008), this repealed all but the Special Consent procedures of the Ordinance.

In the case of eThekwini, the rationale for decision-making in the public interest draws from the previous provincial planning legislation, the TPO, as amended, whereby planning decisions are required to uphold the purpose of the Scheme. ${ }^{1}$ While the TPO was substantially amended, largely replaced by the KwaZulu-Natal Planning and Development Act (No. 6 of 2008), and has subsequently given way to SPLUMA, with its normative principles to guide development and planning decisions, the instrument of the Scheme prepared under the TPO persists (RSA 2013). ${ }^{2}$ The Scheme embodies existing and potential development rights, including the type of land-use and density controls related to a portion of land. The Scheme, as a plan and set of regulations, is the outcome of a planning process. In this case study, the Scheme is the outcome of orthodox planning on the Berea, with specific assumptions of who constitutes the public. While political ideologies and demographics have changed, the

1 Section 40 of the Natal Town Planning Ordinance (No. 27 of 1949), as amended: "Every structure plan, development plan, town planning scheme (hereinafter in this ordinance referred to as a scheme) or package of plans shall have for its general purpose a co-ordinated and harmonious development of the municipal area, or any area or areas situate therein, to which it relates (including where necessary the reconstruction and redevelopment of any part which has already been subdivided, whether there are or are not buildings thereon) in such a way as will most effectively tend to promote health, safety, order, amenity, convenience and general welfare, as well as efficiency and economy in the process of development and the improvement of communications." (TPO 1949: 51)

2 Subsequent to the research, it is noted that eThekwini Municipality has prepared Planning and Land Use Management By-Law, 2016 in terms of the Local Government: Municipal Systems Act (No. 32 of 2000), for the regulation of framework and procedures related to managing land use. These bylaws were adopted on 1 August 2017, but had at the time of publication not as yet been gazetted. notion of 'who constitutes the public' is still contested and practised within the confines of formal landowners and formal tenants. In this article, orthodox planning is reflected in the assumptions made by broader stateled plans that enable and entrench land uses in Schemes, as well as the state-mediated response to formal planning applications to initiate land-use changes within Schemes. Assumptions include suitable space requirements, related to household size, income levels, and modes of transport, all of which have changed.

\section{METHODOLOGY}

This article uses the case of the Berea neighbourhood in the City of Durban to assess the responsiveness of orthodox planning to current sustainable neighbourhood legislative and policy initiatives.

The history of the area is enmeshed in the legacy of apartheid city socio-economic and political spatial fragmentation on the basis of orthodox modern planning tools, especially zoning. In line with the apartheid doctrine, the Berea was largely conceived as a suburban White residential area. In the northern parts of the area, suburbs such as Morningside, Musgrave, Essenwood, and Windermere were zoned for White residential occupation. The same applies to the suburbs of Umbilo, Glenwood, Bulwer and Congella in the south. The study area and main places in the Berea are shown in Figures 1 and 3, respectively, and listed in Table 1.

The study boundary is aligned to eThekwini Municipality Berea local area planning and administrative boundary, as spelt out in the Berea Urban Core Extension Project Boundary, which extends beyond the Berea South and Berea North Town Planning Scheme areas (lyer Design Studio, 2012a: 11). The Berea is bounded by Cato Manor and Overport and Sydenham to the west, the inner city and the Central Business District (CBD) and the harbour to the east, the Umgeni River to the north and the Umbilo River to the south.
The study relied on primary and secondary data sources. Secondary data focused on content analysis and historical review of the Berea Scheme from 1857 to the present; the Central Durban Application Register of the eThekwini Land Use Management Unit and South Africa Demographic Census data for 2001 and 2011(Statistics South Africa, 2001; Statistics South Africa, 2011). Content analysis of orthodox planning tools on the Berea focused on the history of the Berea general plans and related title deed restrictions on land use from 1857 to the present, with specific reference to land-use controls for building height, coverage, building densities, and building form and function. Content analysis of the Central Durban Application Register of the eThekwini Land Use Management Unit focused on analysis of land-use change dynamics on the Berea, based on GIS mapping of the contraventions, pressure of land-use change, densification, approved business applications and types of planning applications. Content analysis of the Statistics South Africa Demographic Census between 2001 and 2011 examined the total population of the Berea, racial and sex composition of the population; household size and income dynamics. In addition to secondary data, primary data on the planning of the Berea vis-à-vis sustainable neighbourhood change was obtained from key informant interviews with practice-based planners with experience over three decades in the Berea, including two municipal planners and two private sector planning consultants. In terms of collecting data from the interviews, the researchers conducted in-depth, unstructured interviews to substantiate and supplement observations made by the researchers through purposive sampling (Denzin \& Lincoln, 1998: xiv). The interviews followed the central research question of how planning tools respond to neighbourhood change.

\section{FINDINGS}

As noted earlier, the findings of the research are based on a review of 
the evolution of orthodox planning on the Berea, supported by analysis of land-use change applications, supplemented by unstructured interviews and recorded observations and, lastly, through demographic analysis of change on the Berea between 2001 and 2011 .

\subsection{Finding 1: Review of the evolution of orthodox planning on the Berea}

Land use was managed in the early development of the Berea, before modernist and orthodox planning instruments of the 1950s, through restrictive conditions on title deeds and by-laws. Specifically, those restrictive conditions referring to building types, building materials and servitudes provided the main instruments for managing land use. Durban depicted differential controls relating to race and class both within the Berea (lower and upper) and between areas such as the Point, Congella and central town. Prior to the 1950s, Durban had a myriad of regulations and by-laws for managing land use. In 1952, partly in response to consolidate residential regulations across the City and partly in response to the new planning legislation (Province of Natal, 1949), Durban prepared a report on regulation of building and control of land use (City of Durban, 1952) along with the first city-wide zoning notation map (see Figure 2). In December 1952, the City Council adopted an amended report that extracted from the 1950 report those issues relating to residential matters and was entitled "Regulation of Land and Control of Land Use (Residential Areas) and Preparation of Town Planning Scheme" (Circular No. 561). The earlier report dated August 1950 was compiled by the City Engineer, Mr H.A. Smith, and framed the Town Planning Scheme under the Ordinance (No. 27 of 1949).

The TPO (brought into effect in 1951) made provision for the preparation of Town Planning Schemes by municipalities. While the earlier provincial statute, the Private Townships and Town Planning Ordinance (No. 10 of 1934) also made provision for Town Planning Schemes, these early schemes were critiqued for being inflexible, with an absence of planning procedures to initiate and appeal rezoning applications locally, although an owner could lodge an appeal with the Supreme Court.

As a reflection of the political context with the introduction of petty apartheid in 1948, the Durban land-use regulations, prepared by H.A. Smith, the City Engineer, make mention of non-European servants' quarters with differentiated floor space. It could be argued that the recognition of servants' quarters was a method to entrench the discriminatory policies of the time relating to socio-economic segregation. The regulations bring class differentiation into the scheme.

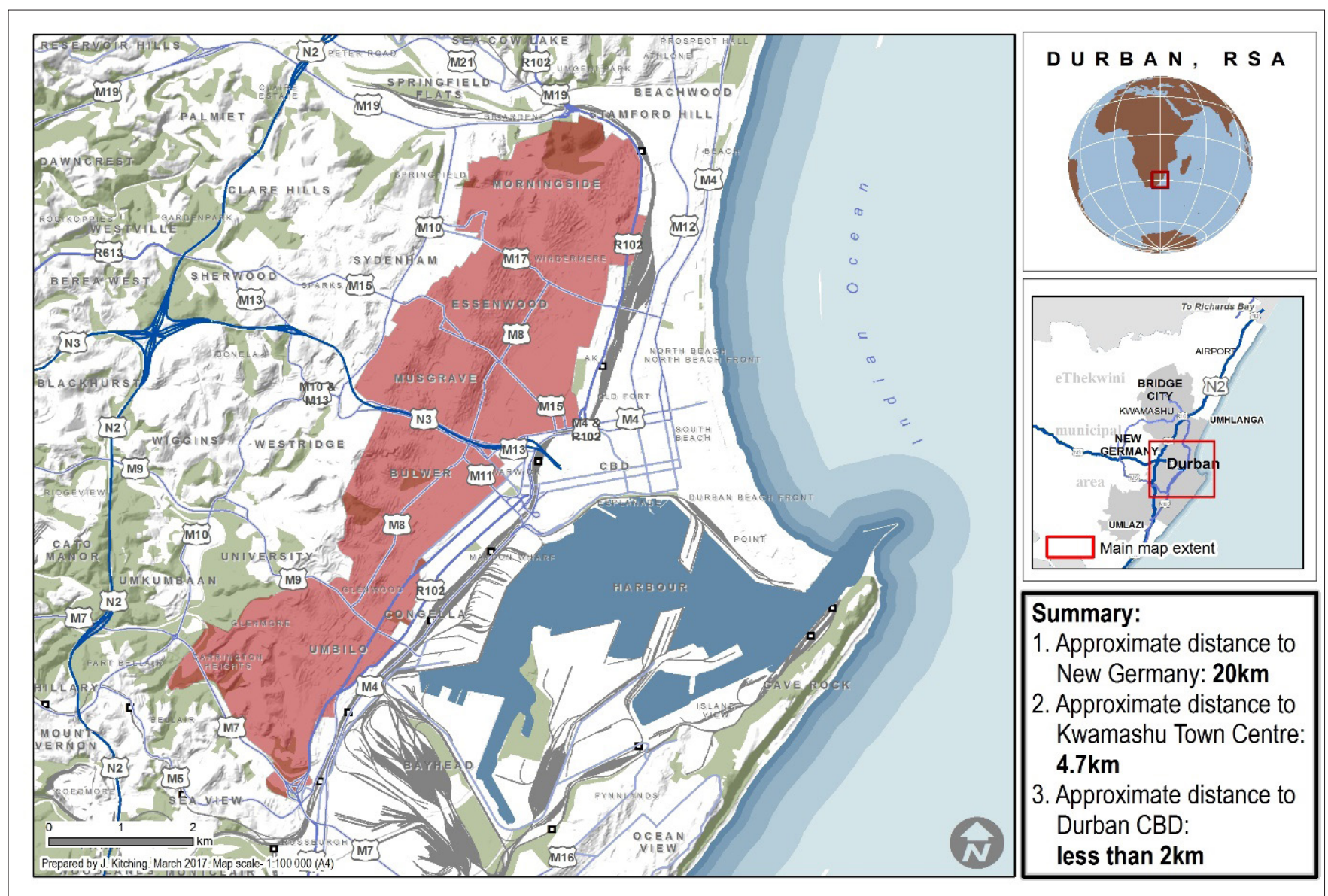

Figure 1: Locality plan of Berea

Source: $\quad$ Map prepared by J. Kitching, 2017 
Portions of the upper Berea are reserved for single dwelling houses, while specific areas are zoned for other residential buildings such as apartment houses, boarding, residential clubs, convalescent homes, flats, hotels, hospitals, institutional residential buildings, sanatoriums, and nursing homes (City of Durban, 1952: 3). In line with the implementation of apartheid through forced removals, the Group Areas Act, among other laws, and resultant public works programmes, the state also invested in public housing for government workers. The remnants of mixed institutional housing with private dwelling currently persists on the Berea, and are some of the areas where significant demographic, class and ethnic change is experienced, or what Schensul and Heller (2011b: 4) refer to as "residential racial mixing or desegregation".

Largely influenced by the earlier 1952 regulations, the Berea Town Planning Scheme came into effect on 6 December 1954 and the 'Rezoning of the Berea' as was adopted (City of Durban, 1954). The Map of the Durban Scheme (within which the Berea forms a part), depicted in Figure 2, forms the basis of the 1953 Scheme, but the colours are an accumulation of amendments made through re-zonings for an unconfirmed period, which may have ended in the early 1960s. Differential land use by class and race is clearly evident in the Scheme, where direct reference to the Group Areas Act (No. 41 of 1950) is made and the western part of the Berea reserved for "Asiatic occupation" and the ridge line identified as suitable for "European occupation" (City of Durban, 1954: 10-11). Concepts such as the high Berea with larger plot sizes and protection from flat development was implemented above the McDonald, Brand, Bulwer, Botanic Gardens, Cowey, Gordon and Windermere Road line. The Town Planning Scheme also set aside substantial areas for parks, open space, schools and hospitals. The influence of garden-city ideas, centred on neighbourhood-scaled amenities, is evident in the design. Large portions of the lower Berea were zoned as General Residential in response to post-war growth and anticipation of demand for residential development closer to the city centre. Land use is currently managed in terms of this Scheme. Although there are amendments, the structure persists.

The Scheme was reviewed in 1973, following the City Engineers Report on Planning the Berea (1965) and the Berea Outline District Plan (1967). The Scheme revision addressed the concerns of providing recreational space, allowing highrise developments in the lower Berea (City of Durban, 1972: 397) and preparing consolidated Town Planning Regulations. The 1973 revision informed by the "City Engineers Report on Planning the Berea (1965)" contains Orthodox Planning tools such as planning standards and thresholds to guide the future development of the Berea.

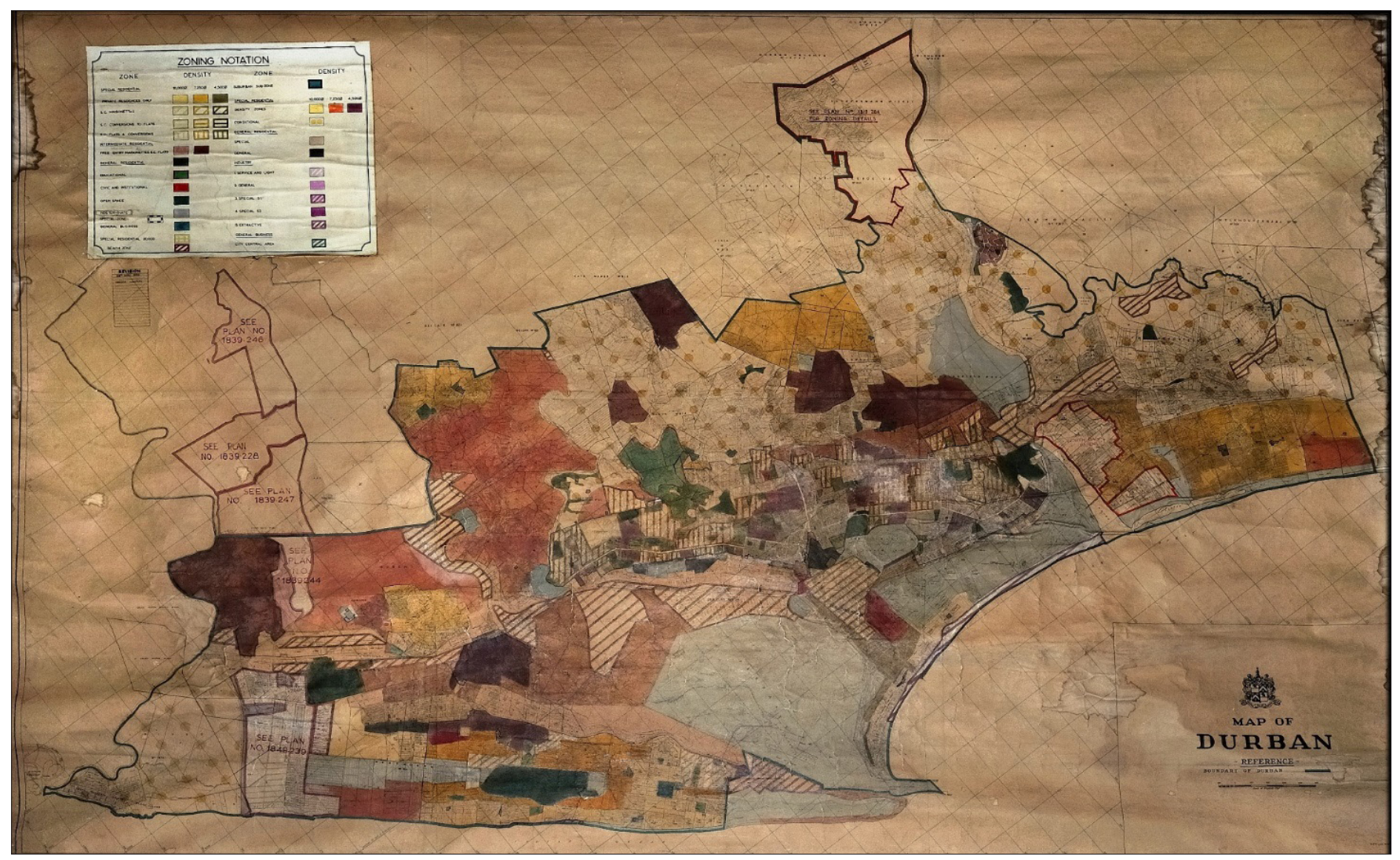

Figure 2: $\quad$ First City of Durban Town Planning Zoning Plan, 1952

Source: $\quad$ Scan of Map from eThekwini Municipality, 2016 


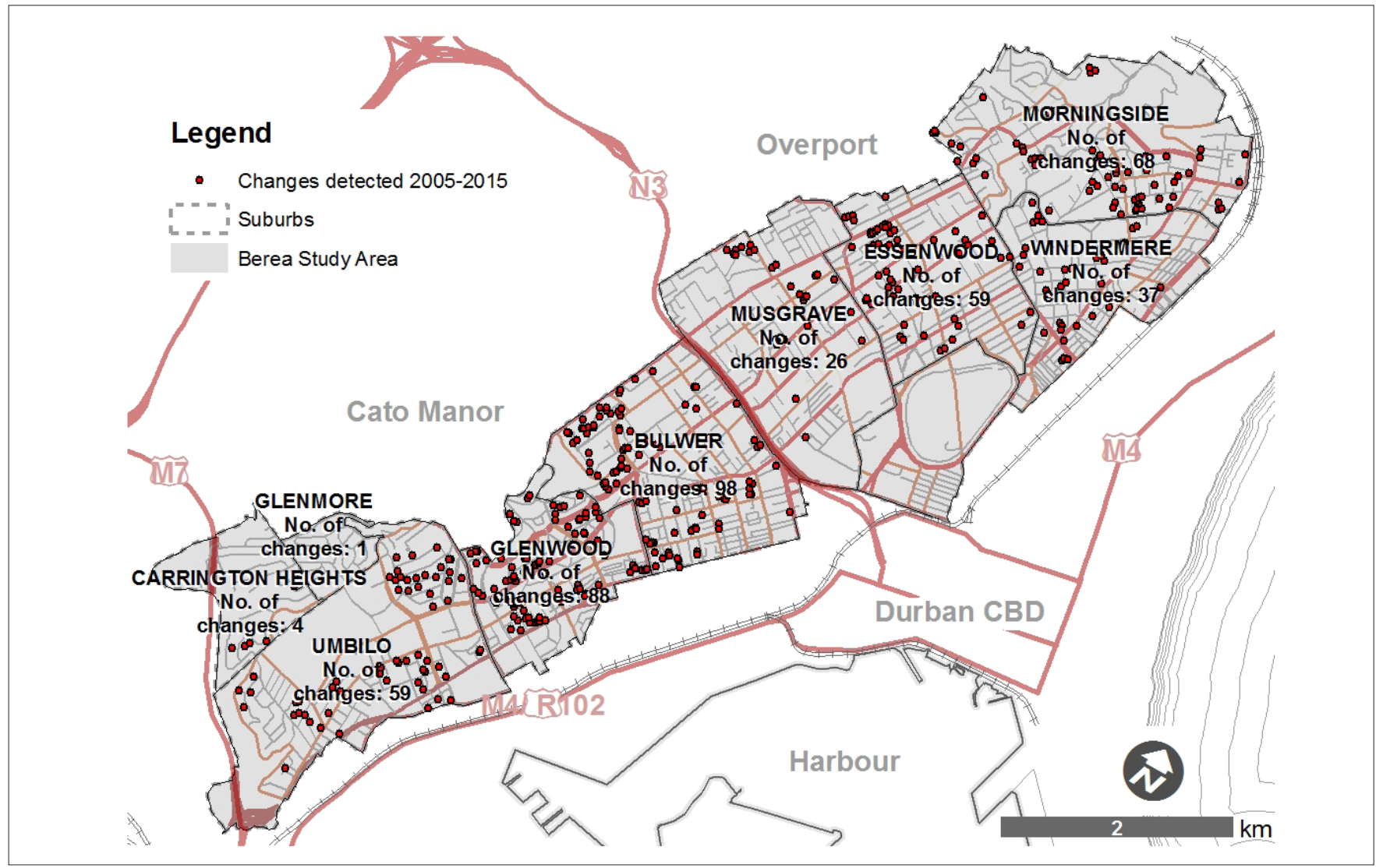

Figure 3: Distribution of floor area changes between 2005 and 2015

Source: $\quad$ Adapted from eThekwini Municipality Central Durban Application Register by DUT GIS Unit, 2016

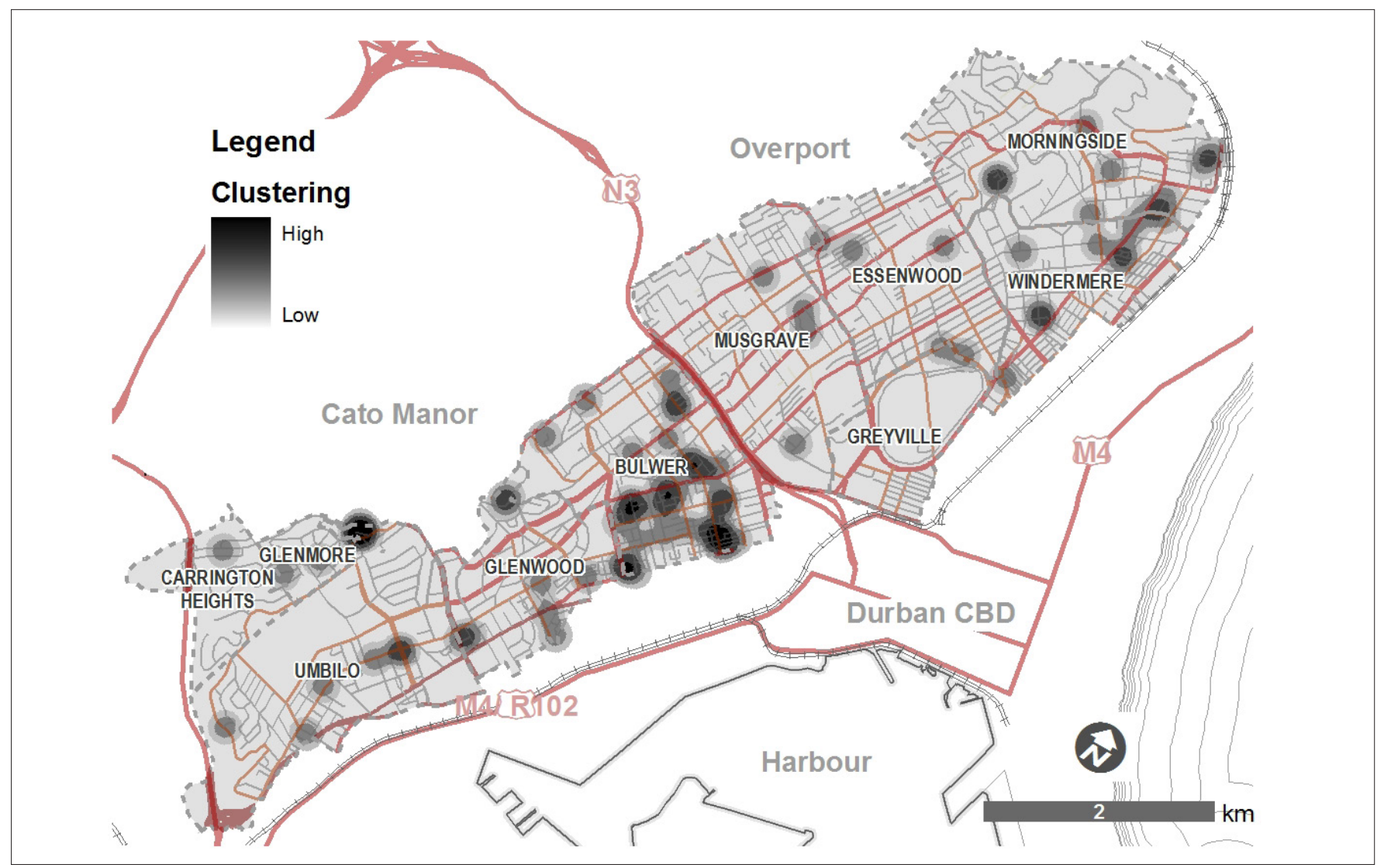

Figure 4: Distribution of contravention on the Berea 2012-2016

Source: $\quad$ Adapted from eThekwini Municipality Central Durban Application Register by DUT GIS Unit, 2016 
Assumption of household sizes and required level of amenities appropriate to the Berea are made explicit and differentiated the Berea from Umgeni South, including the back of the Berea. Despite changes in the national and provincial planning system, the regulations adopted on 14 December 1973 related Town Planning Scheme Map, amended from 1965, persist in current scheme maps.

The introduction of IDPs in South Africa from 2000 saw planning for the City of Durban taking place within this local government restructuring framework, including the preparation of Local Area Plans (LAPs) for the districts of the city. For the Berea, Gordon and Hansmann (2007: 207) note pressures from business and office uses to locate in established residential areas of the Berea and this culminated in the eThekwini Council commissioning work to prepare and develop a land-use management plan and development guidelines for the Berea. They highlight that this led to the development of the Urban Core Extension Policy of 2001. Its purpose was not to replace the 1973 Town Planning Scheme, but to align proposed land-use change applications with the Berea Urban Core Plan (2001) without changing density and floor area. The attempt to review the scheme started with a provincial project by the Planning and Development Commission for more appropriate land-use controls in 1999. Following this initiative, Durban commissioned the Berea Urban Core Extension Project (2001) and ultimately approved a set of land-use guidelines with land-use intentions in 2001 and reviewed in 2004 and again in 2011. These initiatives included normative planning principles in line with those expressed in the Development Facilitation Act (No. 67 of 1995). The introduction of land-use intentions are different to zonings, by adding normative statements to the zone, linking these to higher order plans and clarifying future intended development. The project was critiqued, as the land-use intention did not accompany revised density controls, which conservatively limited changes to the existing built form of the Berea.

\section{By 2012, eThekwini Municipality} undertook a substantial review of the Berea plans. This led to the Berea Urban Core Extension project (2012) including a land-use management framework, implementation and conceptual precinct plan report and the translation of the functional area plan of the urban core extension into a draft Scheme as part of the Durban scheme (lyer Design Studio, 2012b; Iyer Design Studio, 2013). The revised plan for the Berea highlights that penetrating new and other uses "challenges the existing scheme and current infrastructure" (lyer Design Studio, 2012a: 11). The new vision and land-use framework for the Berea, spelt out in the Berea Urban Core Extension Policy of 2012, created a plan to inform the preparation of the proposed new Scheme. However, despite attempts to advertise and revise the new Scheme, some four years later, the proposals were not adopted and the 1973 amended Scheme persists. Furthermore, it is worth noting that, although the Berea Urban Core Plan has not been formally adopted, it is being used as an informant document for statutory applications in this area.

\subsection{Finding 2: Analysis of land- use dynamics}

The Central Durban Application Register of the eThekwini Land Use Management Unit includes 9,736 building plan records, 3,638 business licence records and 5,834 planning applications across the study period 2 May 2012 to 26 January 2016. The 387 records for the Berea North and South study area were georeferenced and extracted through GIS from the overall register database. Anonymity was applied to property point data by applying a 200-meter buffer to the data. The data consists of 82 contraventions to the Scheme, 354 planning applications, and 100 business licence applications. A key limitation to the Register is that public space and, specifically, informality in public spaces are not captured under property descriptions. Observations were used to overcome the shortcomings and supplement the study. The study also compared the 2005 GIS built form survey with an updated survey from 2015 to identify the distribution of floor area changes shown in Figure 3.

\subsubsection{Contraventions}

Contraventions of land use are reported to eThekwini Municipality, either as public complaints or by officials, and identified as uses not permitted under the planning scheme. Almost one quarter of the contraventions are shown as illegal uses, $10 \%$ relate to student accommodation and a further $10 \%$ as informal activities (spaza shops and taverns). The remainder relate to site-specific complaints impacting on amenity. The concentration of contraventions, in the neighbourhood of Bulwer (40\%) and Glenwood $(10 \%)$, is significant during the data period shown in Figure 4. Pressure for land-use change is being expressed in Bulwer and Glenwood and depicts pent-up demand for relatively affordable commercial access to land markets. It was also observed that residential stock is being eroded to commercial and office use rather than mixed use.

Significantly, the push for densification as a way of achieving one of the normative planning principles within the new planning framework, was ushered in with the changing of political leadership in the city in 2007. This has presented a key challenge to orthodox planning, as the normative base of densification is not accommodated in the planning standards.

The following types of activities associated with densification were observed and shown in Figure 3 and 4:

- On the edges of the Berea, in existing public housing stock, that is informal and somewhat unregulated, for example, police housing/military personal, and other public sector workers.

- Close to institutions, for example universities. Both higher education institutions in the eThekwini municipality are home to some of their campuses on the Berea, and host some 55000 students. This represents 
a significant increase of take-up in higher education over the years. It can be argued that enrolment planning for students has not been matched with the necessary residential infrastructure, hence an increase in densification around student accommodation both provided by the institutions and the private sector letting market. It is not uncommon for up to six students to be renting two-bedroomed flats, or for sub-letting university residences.

- New opportunities through the densification strategy, as shown in Figure 3, indicating increased floor area, and that is largely market driven.

\subsubsection{Approved business applications}

The type of business applications relates to fast-food outlets, restaurants, tuck shops, taverns, supermarkets, bed and breakfast, student accommodation, guest houses, gambling outlets, as shown in Figure 5. These applications tend to be concentrated in the local entertainment corridors of Helen Joseph (Davenport) Road, Florida Road and Lillian Ngoyi (Windermere) Road, where restaurants, fast-food outlets and pubs tend to agglomerate. In the interview on 1 March 2016, Parker (Regional Coordinator within the Land Use Management Branch, eThekwini Municipality) confirmed that the establishment of late night entertainment, including night clubs and music venues, in these areas has been met with resistance from local residential areas and created challenges for the city officials.

The above findings reflect landuse changes in established neighbourhoods and strip entertainment areas, without layering informal and temporal entertainment activities.

\subsubsection{Types of planning applications}

Applications for relaxations and special consent approvals are made in terms of the Scheme clauses, enacted by the KwaZuluNatal Town Planning Ordinance of 1949 , as amended. The majority of applications, 260 out of 354 $(73 \%)$ relate to relaxations on plan submissions, including buildings line, height, coverage and FAR. Special consents, usually related to a land-use change, amounted to 74 of $260(28 \%)$ of applications in the four-year period, using orthodox planning instruments and informed by orthodox assumptions, and are shown in Figure 6. There is also a contradiction between the normative principles of walkable and sustainable neighbourhoods and the use of orthodox instruments that measure planning applications according to parking requirements, for example. Hence, the planning

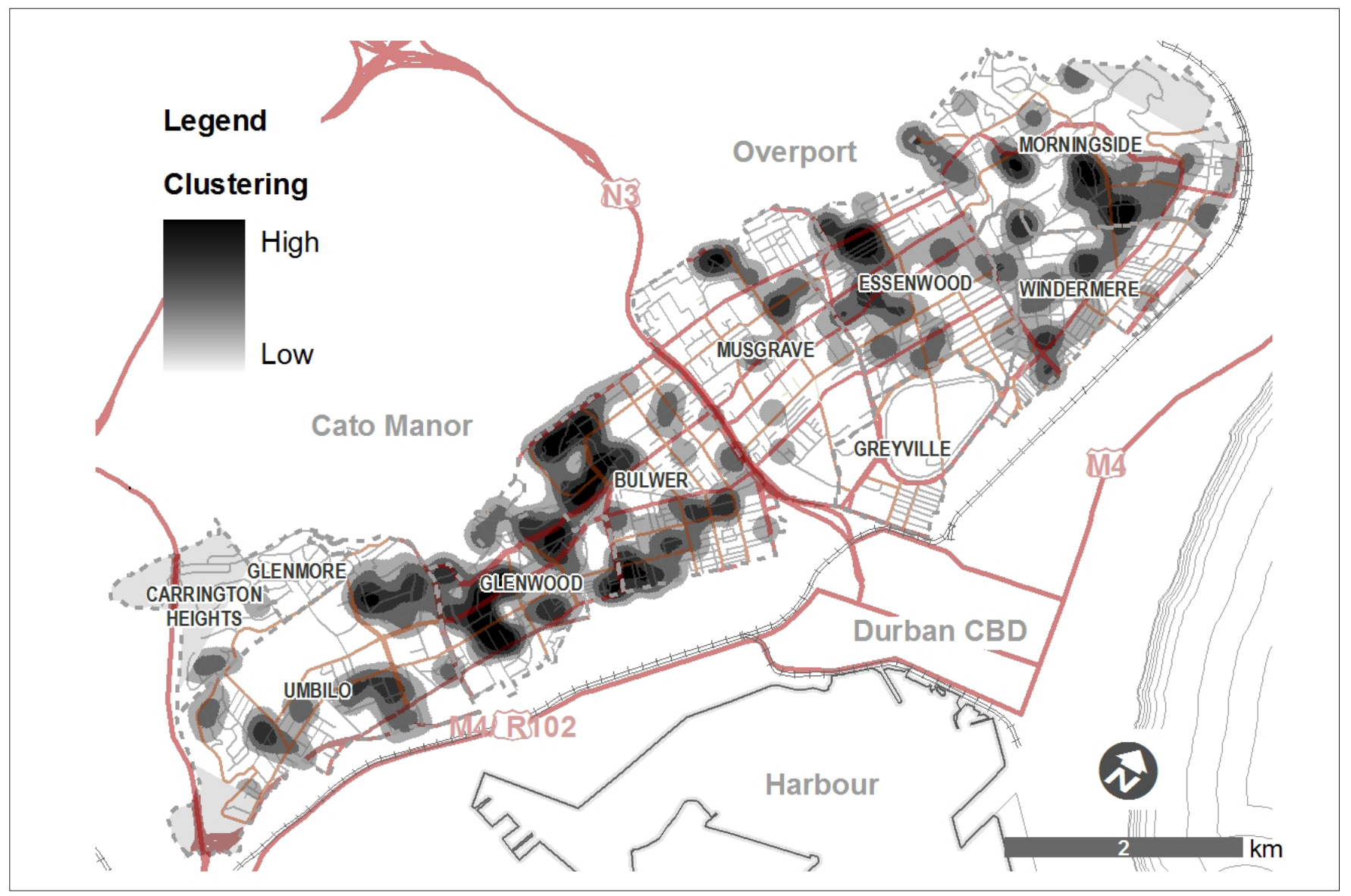

Figure 5: Distribution of business application on the Berea 2012-2016

Source: $\quad$ Adapted from eThekwini Municipality Central Durban Application Register by DUT GIS Unit, 2016 
for public transport use (Integrated Rapid Public Transport Network), densification, off-site parking areas, and non-motorised options are difficult to factor into planning arguments and are generally not taken into consideration.

Furthermore, the spread of applications across the Berea reflects a dynamic context of land-use and activities change, and questions the way in which applications are being assessed - orthodox or normative? This spatial distribution of applications also challenges the view that densification would only happen on the lower Berea in the general residential zones, as per the early Scheme assumptions, or along corridors, as identified in Figure 6.

Rezoning applications, in terms of the Provincial planning legislation, the KwaZulu-Natal Planning and Development Act (No.6 of 2008) (PDA), tend to change both use and density controls, presenting a recent move on the part of the municipality towards densification of the Berea in line with the intentions of the Spatial Development Plan. However, these applications appear to be largely speculative, private sector-led rather than a reflection of the public interest and normative intentions. In the interview on 3 March 2016, Clarke (eThekwini Municipal Official) raised the challenge of reconciling the normative intentions of SPLUMA, especially in already built area, with implementing traffic and transport parking standards. Some precincts were considered more suitable than others for change.

The intention of the more recent Berea plan (2012) is strongly normative, with elements of new urbanist principles related to developing "well contained, safe and secure residential neighbourhoods, well-structured open space systems, focus on human-scale mixed-use business clusters; and supportive public transport service" (lyer Design Studio, 2012b: 25). Areas of significant change in the plan are corroborated by this research and include substantial office conversion of existing residential housing stock, entrenchment of the Florida Road entertainment corridor, consolidation of the Helen Joseph (Davenport) Road entertainment strip and, more recently, the emergence of the Lillian Ngoyi (Windermere) Road local entertainment corridor. When interviewed on key land-use changes on 3 March 2017, Ferguson (Planning Consultant) noted the urban management improvements of the Florida Road Urban Improvement District (UIP) with visible policing and public maintenance, alongside the displacement of informal car guards to the Lillian Ngoyi (Windermere) Road strip some distance away.

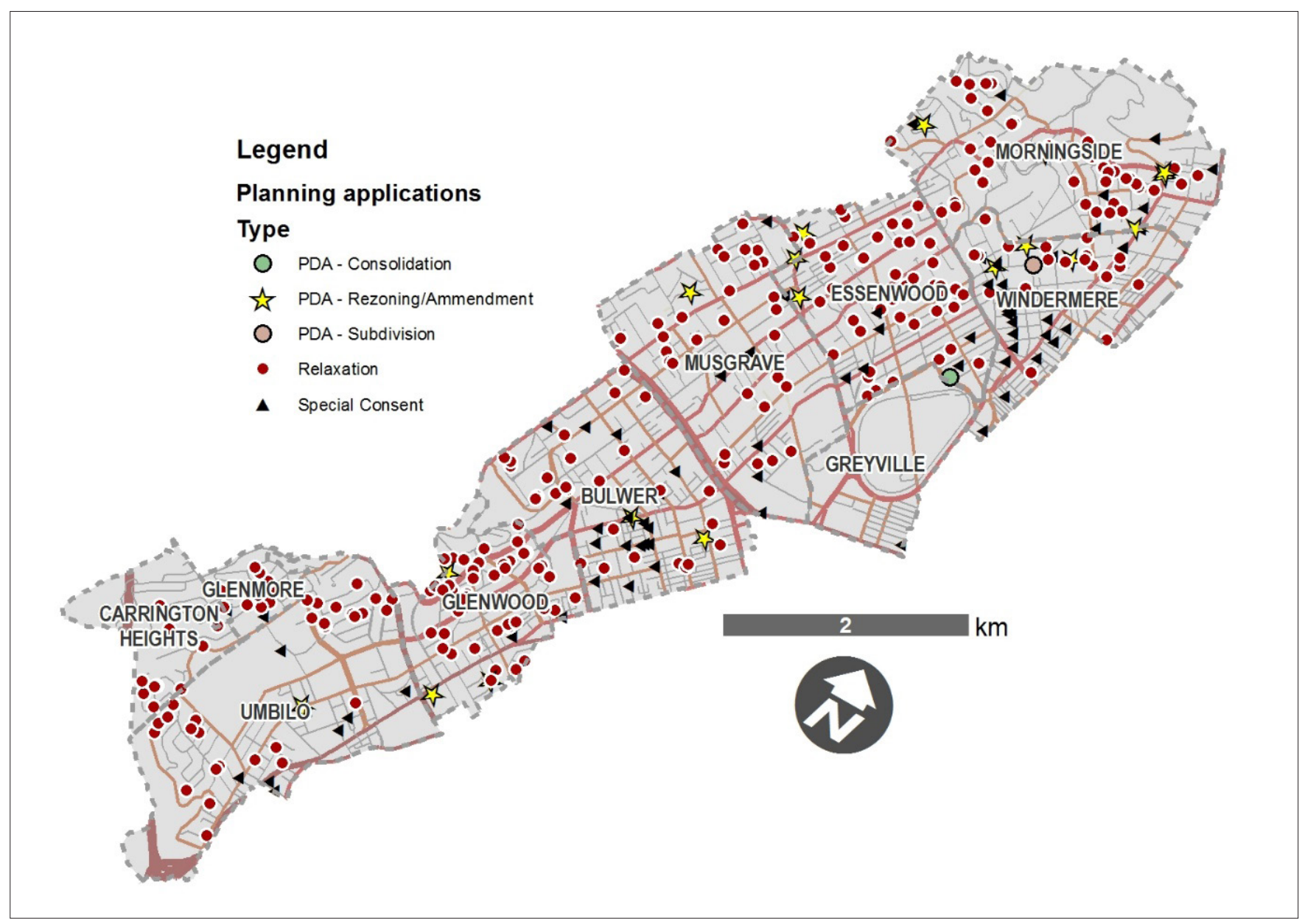

Figure 6: Distribution of the type of planning applications on the Berea 2012-2016

Source: $\quad$ Adapted from eThekwini Municipality Central Durban Application Register by DUT GIS Unit, 2016. 
Durban is at a moment where normative planning concepts based on a set of principles, particularly those related to sustainability, are being introduced into the planning framework. These frameworks stand in contrast to Schemes, steeped in orthodox planning concepts such as neighbourhood planning and planning standards with entrenched assumptions on who constitutes the neighbourhood. As neighbourhoods change, residential stock is depleted, commercial stock encroaches, residential occupancy rates fluctuate, and informality grows. Thus, the need to reflect and be more responsive to neighbourhood change is more urgent.

\subsection{FINDING 3: DEMOGRAPHICS OF THE BEREA}

Demographic changes correspond strongly to density and to land-use changes in the four local government administrative and political wards of the Berea area, namely wards 27,31 , 33, and 101, as shown in Table 1.

The sub-places in Table 1 were used for enumeration purposes in the 2001 census that was conducted by Statistics South Africa.
However, some sub-places were collapsed into one sub-place the 'Berea' for purposes of the 2011 census sub-place enumeration. These are Umbilo, Glenwood, and Bulwer (Berea South) and Musgrave, Windermere, Greyville, and Morningside (Berea North). The areas that were left as standalone sub-places for 2011 census enumeration are Glenmore (SouthWest Berea), Carrington Heights (South West-Berea), and Essenwood (North-West Berea).

Based on the 2001 and 2011 census data, there has been a significant demographic shift in the Berea area with regards to the physical and socio-economic characteristics of the population (Statistics South Africa, 2017). The total population of the Berea area, based on the population per sub-place from Statistics South Africa, was approximately 94135 in 2001, as shown in Table 1. This increased to approximately 127887 in 2011 , translating into $35.90 \%$ population change.

In 2001, the population size per racial group in descending order was White (49 645); Black (21 119); Indian (13 112), and Coloured (10 261). This contrasts with 2011,

Table 1: $\quad$ Sub-place names in the Berea area per ward

\begin{tabular}{|c|l|}
\hline Ward & \multicolumn{1}{|c|}{ Sub-place names } \\
\hline 27 & Essenwood, Windermere, Greyville, Morningside, and Stamford Hill \\
\hline 31 & Sparks, Musgrave \\
\hline 33 & Umbilo, Glenwood, and Bulwer \\
\hline 101 & Westridge, University, Glenmore, and Carrington Heights \\
\hline
\end{tabular}

Source: StatsSA 2001; StatsSA 2011

Table 2: Population by racial group in the Berea in 2001 and 2011

\begin{tabular}{|l|c|c|c|}
\hline \multicolumn{1}{|c|}{ Racial group } & $\mathbf{2 0 0 1}$ & $\mathbf{2 0 1 1}$ & \% change \\
\hline Black & 21119 & 51422 & 143.50 \\
\hline Coloured & 10261 & 11383 & 10.90 \\
\hline Indian or Asian & 13112 & 32226 & 145.85 \\
\hline White & 49645 & 32856 & -33.80 \\
\hline Total & 94137 & 127887 & 35.90 \\
\hline
\end{tabular}

Source: StatsSA, 2001; StatsSA, 2011

Table 3: Population by sex in the Berea in 2001 and 2011

\begin{tabular}{|l|l|l|l|}
\hline \multicolumn{1}{|c|}{ Sex } & \multicolumn{1}{c|}{ 2001 } & \multicolumn{1}{c|}{ \% change } \\
\hline Female & 51529 & 69267 & 34.40 \\
\hline Male & 42598 & 60407 & 41.8 \\
\hline
\end{tabular}

Source: $\quad$ Stats SA, 2001; Stats SA, 2011 
Table 4: $\quad$ Household size in 2001 and 2011

\begin{tabular}{|c|c|c|c|}
\hline Household size & $\mathbf{2 0 0 1}$ & $\mathbf{2 0 1 1}$ & \% change \\
\hline 1 & 13374 & 17800 & 33.09 \\
\hline 2 & 10529 & 12799 & 21.56 \\
\hline 3 & 5283 & 7021 & 32.9 \\
\hline 4 & 3883 & 5544 & 42.78 \\
\hline 5 & 1883 & 2618 & 39.03 \\
\hline 6 & 778 & 1264 & 62.47 \\
\hline 7 & 305 & 519 & 70.16 \\
\hline 8 & 154 & 288 & 87.01 \\
\hline 9 & 41 & 131 & 219.5 \\
\hline $10+$ & 71 & 120 & 69.01 \\
\hline Total & 36301 & 48104 & 32.51 \\
\hline
\end{tabular}

Source: Stats SA, 2001; Stats SA, 2011

Table 5: Household income in 2001 and 2011

\begin{tabular}{|l|c|c|c|}
\hline \multicolumn{1}{|c|}{ Household income } & $\mathbf{2 0 0 1}$ & $\mathbf{2 0 1 1}$ & \% change \\
\hline No income & 2396 & 5709 & 138.3 \\
\hline R1 - R4 800 & 744 & 738 & -0.806 \\
\hline R4 801 - R9 600 & 2687 & 956 & -64.42 \\
\hline R9 601 - R19 600 & 3349 & 3338 & -0.328 \\
\hline R19 601 - R38 200 & 4287 & 4475 & 4.385 \\
\hline R38 201 - R76 400 & 6815 & 5341 & -21.63 \\
\hline R76 401 - R153 800 & 7755 & 7345 & -5.287 \\
\hline R153 801 - R307 600 & 5449 & 8205 & 50.58 \\
\hline R307 601 - R614 400 & 1938 & 5941 & 206.6 \\
\hline R614 001 - R1 228 800 & 473 & 2340 & 394.7 \\
\hline R1 228 801 - R2 457 600 & 247 & 617 & 149.8 \\
\hline R2 457 601 or more & 164 & 359 & 118.9 \\
\hline
\end{tabular}

Source: StatsSA, 2001; Stats SA, 2011

(R30 7601 and above) makes up just over $19 \%$ of the whole.

Table 5 shows that there was a significant increase in households with no income, a development that could be alluded to the increase in the number of students in the area, falling employment levels, and growth in the informal sector. On the other hand, there were also increases in households in the middle- to high-income categories, suggesting growing inequalities. This research points to some of the inadequacies of changing land uses without revisiting the assumptions of who is being planned for and changing household, demographic, and occupancy rates on the Berea.

\section{DISCUSSION OF FINDINGS}

In post-1994 South Africa, orthodox planning tools for suburban neighbourhood planning have failed and came into effect in 1969, based on modernist planning tools and standards for promoting amenities such as building height restrictions, building coverage control, city beautification in terms of aesthetics and landscape design, density control, and differentiation of neighbourhood space through zoning. These orthodox planning tools in the Berea Scheme have been overlaid by the current land-use planning policy narrative of promoting sustainable neighbourhoods densification and socio-economic spatial integration, as reflected in the Berea Urban Core Extension initiative. The contradiction is that new neighbourhood planning tools have not been implemented alongside these new neighbourhood planning policy narratives and initiatives, raising issues on planning capacity to initiate change. This is emphasised by a neighbourhood planning scheme that is still in place on the Berea, reflecting modernist orthodox planning traditions with strong racial and class elaborations, overlain by compliance driven planning decisions. In addition, land-use changes have emerged with regards to densities, and socioeconomic activities on the edges of the Berea that form part of zones of transition from the exclusively White suburban neighbourhood into largely formerly exclusively Indian neighbourhoods, combined with informal settlements.

The contradictions between the orthodox planning scheme in use on the Berea and the current planning policy trajectories and dynamics underscore that planning tools in the scheme are insufficiently responsive to current changes in built environment form and function emerging from demographic shifts in the area. Demographic shifts towards an increase in student population, number of households, emergence of bigger households with more than 4 to 10 people, households with no income, and the diversity of racial and income group mix has brought about built environment forms and functions that are considered to be in contravention of the scheme. These relate to multi-functional usage of 
space for formal and informal socioeconomic activities, higher residential density requirements, and contested use of public space, reflecting not only a mismatch between land-use intentions and actual use, but also questioning whether the spaces are appropriately designed and responsive to a broad range of public interests.

The demographic analysis for the Berea demonstrates that its population changed by approximately $35 \%$ between 2001 and 2011. This change is, however, not indicative of dynamics within the different racial groups. Whilst the Black and Indian population groups experienced changes of over $140 \%$, the White racial group plummeted, recording a change slightly above $-33 \%$. The Coloured group experienced a change of approximately $10 \%$. The population growth trends reflect a general increase in the number of households, increases in relatively bigger households with 5 people and more, diversification of household income levels (increase in both households with no income and middle-income households), and an overall increase in population densities, especially areas surrounding public institutions such as universities and public housing initiatives.

The impact of the demographic trajectories on land-use form and function are reflected in the rezoning applications and contraventions of the Berea Scheme. The findings identify that most of the contraventions of the Scheme have occurred in the context of increases in the densities of dwelling units, due to further subdivisions of houses outside the provisions of the Scheme, as well as changes from residential to commercial usage without the necessary approvals, as reflected in the distribution of contraventions plan.

\section{CONCLUSION AND RECOMMENDATIONS}

The research presented a review of matters relating to the planning, development and management of sustainable cities in the context of the Berea, in the city of Durban, by juxtaposing orthodox planning instruments against the realities of current land-use changes. It is noted that, while there is a broad understanding of what sustainable development is, there is no absolute agreement on its definition and operationalising of sustainable development instruments. For the purpose of this article we support an inclusive definition relating to environmental quality, economic prosperity, governance and social justice in order to achieve potential sustainable development outcomes at a local level and by refining planning instruments to be more inclusive of informality and responsive to transformation imperatives.

It is argued that sustainable city development has been incorporated in broad principle in the eThekwini SDF, particularly principles of densification. However, it is weakly articulated in the planning instruments of land-use management at a neighbourhood level. The SDF and planning system need to be receptive to informality, supporting appropriate indicators and assessment methods in order to ascertain whether the city is achieving neighbourhood level sustainability.

The main findings are that, prior to the introduction of Schemes, land use was managed through by-law regulation and title deed restrictions. Despite the progressive change to normative planning principles from 1994, orthodox land-use planning persists and is still the dominant mode for managing land-use regulations in parts of the city of Durban, and on the Berea, in particular.

A continuing challenge remains the difficulty of shifting from an orthodox planning system, based on fixed investments, to using transformative planning instruments for sustainable neighbourhood development with a more nuanced approach towards densification, working proactively with informality, and a collaborative approach with role players, among others. The point is that planners require a set of values and skills to support transformation. This is reinforced by our observations whereby contraventions to the Town Planning Scheme were recorded, in particular those relating to informality, densification, and contraventions to the Scheme. Transformation policy for sustainable neighbourhoods in post-colonial cities should be accompanied by the concurrent refinement of orthodox planning practices and tools to ensure smooth transitions based on the synergy between the planning tools and policy intentions. In the case of the Berea, unresolved contradictions are apparent between a scheme that uses orthodox planning tools for the creation of amenity, on the one hand, and policy intentions towards sustainable integrated suburban development, on the other.

This research has critiqued the Durban Scheme on the Berea for the absence of an appropriately neighbourhood-scaled spatial plan to inform land-use changes, as well as the absence of frequently revised plans to inform scheme revisions. While land uses are being changed, prompted by applications, the policy framework to inform the changes is insufficiently directive, resulting in ad hoc decisions. This research has shown that orthodox planning tools have been critiqued for their bluntness and lacking in nuanced responses to the existing context.

Whilst our study concentrated on the traditional suburb of the Berea, on the adjacent edges (Cato Manor, Sydenham, Overport) of what used to be African, Coloured and Indian group areas, there is a high degree of pressure relating to informality, densification, visible transgressions of planning controls, and so on. These represent zones of transition and opportunities for innovation, creativity and new practices for neighbourhood planning. Orthodox neighbourhood planning should take cognisance of trends towards increasing socio-economic and racial population mix, where these meet a localised expression of identity, demographic shifts and changes for sustainable neighbourhood goals to be realised. 


\section{ACKNOWLEDGEMENTS}

The authors wish to acknowledge the role of Joe Kitching, DUT Department of Town and Regional Planning, for the GIS mapping and analysis. This article was first presented at the Southern African Cities Studies Conference (SACSC) held in Durban, March 2016. The article was substantially strengthened by the feedback from the blind reviewers.

\section{REFERENCES}

ALLEN, R., ALLABY, M., DAVOLL, J. \& LAWRENCE, S. 1972. A blueprint for survival. The Ecologist, 2(1), pp. 1-43.

ANDREW, D.B. 1995. Methods of defining 'sustainability'. Sustainable Development, 3(3), pp. 109-119. https:// doi.org/10.1002/sd.3460030302

BRENNER, N., MARCUSE, P. \& MAYER, M. 2012. Cities for people, not for profit: Critical urban theory and the right to the city. London: Taylor \& Francis.

BRUNDTLAND, G., KHALID, M., AGNELLI, S., AL-ATHEL, S., CHIDZERO, B., FADIKA, L., HAUFF, V., LANG, I., SHIJUN, M. \& DE BOTERO, M.M. 1987. Our common future ('Brundtland report').

BRUYNS, G. \& GRAAFLAND, A. 2012. African perspectives [South] Africa. City, society, space, literature and architecture. Rotterdam: 010 Publishers.

CITY OF DURBAN. 1952. Amended report on the regulation of building and control of land use for the residential areas being part of the Town Planning Scheme. In: CITY AND WATER ENGINEERS DEPARTMENT (ed.). Durban.

CITY OF DURBAN. 1954. Rezoning of the Berea. In: CITY AND WATER ENGINEER (ed.).

CITY OF DURBAN. 1972. Town Planning Technical Sub-Committee Minutes, dated 19/7/1972.

CITY OF DURBAN. 1973. Durban Town Planning Scheme Clauses.

DENZIN, N.K. \& LINCOLN, Y.S. 1998. Strategies of qualitative inquiry. Thousand Oaks, California: Sage.

DEWAR, D. \& UYTENBOGAARDT, R.S. 1991. South African cities: A manifesto for change. Urban Problems Research Unit, University of Cape Town.
DUNCAN-BROWN, A. 2000. Garden cities. In: South African Planning History Study Group. Proceedings of the Millenium Conference: Planning for Reconstruction and Transformation, 2931 May 2000, Durban. Howard College, University of Natal.

ETHEKWINI METROPOLITAN MUNICIPALITY. 2012. Spatial Development Framework Report 2013/14. Durban: eThekwini Municipality.

GORDON, T. \& HANSMANN, R.J 2007. The case of Durban, South Africa. In: Haccou, H.A. (Ed.). MILU multifunctional and intensive land use. The Netherlands: The Habiforum Foundation.

GUNDER, M. \& HILLIER, J. 2009. Planning in ten words or less:

A Lacanian entanglement with spatial planning. Farnham: Ashgate Publishing.

HALL, P. 2015. 'The city of theory' from cities of tomorrow: An intellectual history of urban planning and design in the twentieth century. $3^{\text {rd }}$ edition (2001). In: Legates, R.T. \& Stout, F. (Eds). The city reader. $5^{\text {th }}$ edition. London: Routledge, pp. 373-385.

HARRISON, P. 2002. Subverting orthodoxy: A re-look at the truths of postapartheid planning. 2002. In: Proceedings of the SAPI "Planning Africa" "Regenerating Africa through Planning" Conference, 17-20 September 2002, Durban, South Africa, pp.1027-1079.

HARRISON, P. \& TODES, A. 2015. Spatial transformations in a "loosening state": South Africa in a comparative perspective. Geoforum, 61, pp. 148-162. https://doi.org/10.1016/j. geoforum.2015.03.003

HARRISON, P., TODES, A. \& WATSON, V. 2007. Planning and transformation: Learning from the post-apartheid experience. London: Routledge.

HARVEY, D. 2016. The right to the city. In: Legates, R.T. \& Stout, F. (Eds). The city reader. $6^{\text {th }}$ edition. London: Routledge, pp. 270-278.

IYER DESIGN STUDIO. 2012a. Berea Urban Core Extension Phase 2 - Development of a FAP/Land Use Management Framework.

IYER DESIGN STUDIO. 2012b. Berea Urban Core Extension Phases 2, 3 \& 4: Land Use Management Framework, implementation and conceptual precinct plan report. eThekwini Municipality, Land Use Management Unit.

IYER DESIGN STUDIO. 2013.

Translation of the functional area plan of the urban core extension into a draft land use management scheme as part of the Durban scheme situational report and preliminary draft scheme. eThekwini Municipality, Land Use Management Unit.

JACOBS, J. 1961. The life and death of great American cities. New York: Random House.

LEFEBVRE, H. 1996. The right to the city. In: Lefebvre, H. Writings on cities. London: Blackwell Publishers, pp. 63-177.

LEGATES, R.T. \& STOUT, F. (Eds). 2015. Introduction, Part 6: Urban planning theory and practice. In: Legates, R.T. \& Stout, F. (Eds) The city reader. $5^{\text {th }}$ edition. London: Routledge, pp. 369-372.

MABIN, A. \& SMIT, D. 1997. Reconstructing South Africa's cities? The making of urban planning 1900-2000. Planning Perspectives, 12, pp. 193-223. https://doi. org/10.1080/026654397364726

MAYLAM, P. 1995. Explaining the apartheid city: 20 years of South African urban historiography. Journal of Southern African Studies, 21(1), pp. 19-38. https://doi. org/10.1080/03057079508708431

MCCARTHY, J.J. \& SMIT, D.P. 1984. South African city: Theory in analysis and planning. Cape Town: Juta \& Company.

MIRAFTAB, F. \& KUDVA, N. 2015. Cities of the Global South reader. London: Routledge.

NEL, V. 2016. SPLUMA, zoning and effective land use management in South Africa. Urban Forum, 27(1), pp. 79-92. https://doi.org/10.1007/ s12132-015-9265-5

PARNELL, S. 1993. Creating racial privilege: The origins of South African public health and town planning legislation. Journal of Southern African Studies, 19(3), pp. 471-488. https://doi. org/10.1080/03057079308708370

PARNELL, S. \& PIETERSE, E. 2010. The 'right to the city': Institutional imperatives of a developmental state. International Journal of Urban and Regional Research, 34(1), pp. 146-162. https://doi. org/10.1111/j.1468-2427.2010.00954.x 
PATRICIOS, N.N. 2002. Urban design principles of the original neighbourhood concepts. Urban Morphology, 6(1), pp. 21-32.

PROVINCE OF NATAL. 1949. Natal Town Planning Ordinance (No. 27 of 1949), as amended. Pietermartizburg: Government Gazette.

\section{RSA (REPUBLIC OF SOUTH}

AFRICA). 2000. Local Government: Municipal Systems Act, Act 32 of 2000. Cape Town: Government Printer.

RSA (REPUBLIC OF SOUTH AFRICA). 2013. Spatial Planning and Land Use Management Act, Act 16 of 2013.

Pretoria: Government Printer.

SCHENSUL, D. \& HELLER, P. 2011a. Legacies, change and transformation in the post-apartheid city: Towards an urban sociological cartography. International Journal of Urban and Regional Research, 35(1), pp. 78-109. https://doi. org/10.1111/j.1468-2427.2010.00980.x

STATSSA (STATISTICS SOUTH AFRICA). 2001. Census 2001 [Online]. Available at: <http://www.statssa. gov.za/?page_id=3892> [Accessed: 15 July 2015].

STATSSA (STATISTICS SOUTH AFRICA). 2011. 2011 Census [Online]. Available at: <http://www.statssa. gov.za/?page_id=3839> [Accessed: 15 July 2015].

STEWART, F. 2015. The sustainable development goals: A comment. Journal of Global Ethics, 11(3), pp. 288-293. https://doi.org/10.1080/17449 626.2015.1084025

STUBBS, M., RATCLIFFE, J. \& KEEPING, M. 2009. Urban planning and real estate development. London: Routledge.

WATSON, V. 1993. The need for more appropriate forms of urban management: The case of land use controls and home businesses. Development Southern Africa, 10(2), pp. 155-166. https://doi. org/10.1080/03768359308439680

YIGITCANLAR, T. \& KAMRUZZAMAN, M. 2015. Planning, development and management of sustainable cities: A commentary from the Guest Editors. Sustainability, 7(11), pp.14677-14688. https://doi.org/10.3390/su71114677 